\section{Paroxysmal Disorder}

Kenneth R. Perrine

Neurological Surgery, Weill Cornell Medicine,

New York, NY, USA

\section{Definition}

A paroxysmal disorder is one in which signs or symptoms develop suddenly (the derivation is from the Greek paroxysmos or paroxyno, meaning to sharpen or irritate). Paroxysms result in spasms, convulsions, or other abrupt onset of physical dysfunction. The term may include almost any bodily system and in neurology is typically used to describe seizure, migraine, or movement disorders. The signs and symptoms of a paroxysmal disorder depend entirely on the particular disorder. In epilepsy, the term is used to denote the cyclical but repetitive onset of sudden attacks, depending on the specific seizure type being described.

\section{Cross-References}

Seizure

\section{References and Readings}

Allan Ropper, A. H., \& Samuels, M. (2014). Adams and Victor's principles of neurology (10th ed.). New York: McGraw-Hill.

Wyllie, E. (Ed.). (2015). Wyllie's treatment of epilepsy: Principles and practice (6th ed.). New York: Lippincott Williams \& Wilkins. 